\title{
KEY DEVELOPMENT FACTORS FOR THE UKRAINIAN ECONOMY
}

\author{
Olha Kryshevych ${ }^{1}$, Olena Terzi ${ }^{2}$, Olha Starytska ${ }^{3}$
}

\begin{abstract}
The aim of the article is to reveal the key factors of economic development of Ukraine at the present stage. In order to achieve the goal, the following tasks are addressed: the main tendencies of Ukrainian economic development are revealed; the main factors of influence are substantiated; the prospects of economic development of the state are considered. The subject of the study is the key development factors of the Ukrainian economy. Methodology. The analysis of legal regulations of Ukraine and scientific literature enabled to examine the current economic situation, the status of Ukraine and to determine strategic priorities and goals of economic development of Ukraine; in addition, dialectical method, scientific abstraction method, methods of system analysis were used. The results of the study revealed the authors' perspective on the strategy, ways, and mechanisms to overcome the systemic crisis and to guide the country to the dynamic growth. The solution of socio-economic problems is linked with the protection and strengthening of demographic potential, priorities of human development, tasks of consolidation of the Ukrainian political nation and formation of an integral socio-humanistic space of Ukraine. Practical implications. The situation and important trends of economic, social, political, legal, and humanitarian development of Ukraine under threats and risks related to crisis processes in the modern world are analysed. The macroeconomic changes, transformations of the real economy, energy, and ecology insecurities are reflected. The issues of achieving effective public administration, overcoming the political crisis, stabilizing the financial sector, developing power - business - civil society dialogue, and transforming the socio-humanistic sphere are considered. Relevance/originality. The study revealed the state of affairs in the economic system of Ukraine, as well as perspective tendencies of the Ukrainian economy were further developed.
\end{abstract}

Key words: factors, economy, economic sector, European integration, strategy.

JEL Classification: $052,017, \mathrm{~L} 1$

\section{Introduction}

In 1991, Ukraine gained only the attributes of a sovereign state. But it did not immediately succeed in filling them with real content. Particularly dangerous was the incompleteness of the development of the national economy. The transition from the administrativedirective to the market economy, from the all-union economic complex to its own economic system could not be painless. This is confirmed by the experience of other countries (Ekonomika Ukrainy v umovakh nezalezhnosti: problemy ta perspektyvy).

As a part of the national economy, there are constant structural, organizational, and other changes that are conditioned by the peculiarities of its economic system and are characterized by certain tendencies and laws of development, which determines the relevance of the chosen topic.

The research of the theoretical and practical aspects of the current state of the Ukrainian economy is carried out in the scientific works of such scholars as N. G. Bazavluk, V. M. Gheits, A. Lazareva, A. Mazaraki, T. Melnyk,
V. I. Melnikova, A. P. Melnikova, S. O. Pavlenko, O. V. Savich, I. V. Savich, V. G. Sevruk, T. V. Sidlyaruk, J. S. Stud, I. Yu. Tour, A. V. Shkurupii, G. M. Shvedova.

To reveal the main factors of economic development of Ukraine at the present stage. To achieve the goal, the following tasks were solved: the main tendencies of the Ukrainian economy development were revealed; substantiated the main factors of influence; prospects of development of the economy of the country are considered.

The development of the world economy in the period up to 2020 will be marked by the influence of a number of factors and megatrends, which will lead to significant changes in the general picture of the world economy and modification of the forms of its organization. Taking into account the place of Ukraine on the brink of Western European and Eastern European Christian civilization, the formation of a new global architecture puts Ukraine in austere geopolitical, geostrategic, and geo-economic challenges, the answers to which it should find in the period up to 2020 .

\footnotetext{
Corresponding author:

${ }^{1}$ National Academy of Internal Affairs, Ukraine.

${ }^{2}$ Odessa National Medical University, Ukraine.

${ }^{3}$ National Academy of Internal Affairs, Ukraine.
} 


\section{The main material}

The world economy has entered the final stage of the world stage of development, during which the European civilization dominated the world. The manifestation of this was the diminution of the role of the US and the West in general in the global economy and international trade and the dispersal of influence and the formation of a new international architecture - both political and financial and economic.

This process raises the challenge to the specific interests associated with the privileges that have provided the individual countries with the existing global financial and economic architecture, so the emergence of a new international order cannot fail due to numerous confrontations (Pro Stratehiiu staloho rozvytku "Ukraina - 2020").

The national economy of any state is a complex economic, social, organizational, scientific and technological system. It has a total economic potential, among which distinguish: natural resource, industrial, labour, scientific and technical.

It should be noted that in the economy of Ukraine in 2016, the slow economic growth trends began. The active increase in capital investment, which was due to unfavourable current trends in both external and domestic markets, while maintaining access to credit and extremely weak budget stimulants indicates healthy processes of adapting the business to macroeconomic risks, responding to competitive challenges, and may precede the stage of cyclical recovery. However, still so far:

- the Ukrainian economy remains weakly diversified and, therefore, vulnerable to fluctuations in world market conditions, characterized by low levels of innovation and resource efficiency. The sources of export-raw material development, which are based on the intensive growth of metallurgical and raw-material exports in conditions of the low exchange rate of hryvnia, are in fact practically exhausted. Ukraine can no longer maintain competitive positions in the global economy at the expense of cheap labour and savings in the development of education and health;

- one of the essential characteristics of the domestic economy is bifurcation: official wages and unofficial, management income and balance, the market value of real estate and balance, etc. (Stud, 2018).

Taking into account the peculiarities of the modern period of national development, which are associated with the emergence of profound political contradictions, not only those measures, which are connected with the elimination of critical backlogs, become extremely important for Ukraine. More than ever, valid and timely actions are taken on the processes of preserving the country's competitive advantages, as well as the strengthening of control over the processes and phenomena that exist in the area of potential threats and are not yet critical (Shkurupii, Bazavluk, 2014).
Factors influencing the formation of the national economy of Ukraine are divided into objective and subjective.

To objective factors include:

- the collapse of the Soviet Union and the breakdown of traditional economic ties;

- significant raw materials and, first of all, energy dependence on other countries;

- deformed, irrational, inefficient structure of the national economy (a highly monopolized, militarized economy with a powerful industrial potential that is difficult to undergo structural restructuring);

- resource-consuming consumable production;

- significant dependence on foreign aid;

- severe consequences of the Chernobyl accident;

- a large share of production in the shadow sector (Melnykova, Melnykova, Sidliaruk, Tur, Shvedova, 2011).

The following subjective factors influence the formation of the national economy of Ukraine:

- the slow progress of market transformations;

- the unpreparedness of the government and the population to reform, difficult and painful process of adaptation to new economic conditions;

- the inconsistency of relations between legislative and executive authorities;

- abolition of the state from the performance of regulated functions, errors and miscalculations of the government;

- insufficient number of qualified specialists (lack of reform team);

- political instability;

- the growth of social tension, huge differentiation of incomes, impoverishment of a significant part of the population;

- the Ukrainian mentality (socio-psychological peculiarities of the nation, which consist of conservatism, caution, excessive tolerance, hope for someone's help) (Melnykova, Melnykova, Sidliaruk, Tur, Shvedova, 2011).

It should be noted that Ukraine has developed a strategy for introducing European standards of life in Ukraine and Ukraine's emergence of leading positions in the world. For this, the movement will be carried forward by such vectors:

$\checkmark$ the vector of development - ensuring sustainable development of the state, the implementation of structural reforms and, consequently, the improvement of living standards. Ukraine should become a strong economy with advanced innovations. To do this, first of all, it is necessary to restore macroeconomic stability, to ensure sustainable growth of the economy in an environmentally friendly way, to create favourable conditions for economic activity and a transparent tax system;

$\checkmark$ the vector of security is the provision of state, business, and citizen security guarantees, protection 
of investments and private property. Ukraine should become a state capable of protecting its borders and securing peace not only in its own territory but also in the European region. The defining basis for security should also be the provision of fair and impartial justice, urgent purges of power at all levels, and ensuring the implementation of effective anti-corruption mechanisms.

At the end of the twentieth century, the world community recognized that corruption is a global problem for every country and that the problem needs to be addressed. The result was the adoption of a whole range of international legal acts (mandatory and recommended), prepared and adopted by the United Nations, the Organization for Economic Cooperation and Development, the Organization of American States, the Council of Europe, the European Union, and the African Union. International legal instruments differed in scope, but all aimed at one - to establish common standards for combating corruption by ensuring the implementation of anti-corruption laws at the national level (Sevruk, 2014). Contemporary organized crime poses a danger not only to the national interests of individual states but is also a direct threat to international security since it has acquired a transnational character. First of all, it concerns countries with an unstable sociopolitical and economic situation, which are at the stage of economic and political transformation, to which Ukraine also belongs (Pohoretskyi, 2007; Pavlenko, 2017).

The leaders of organized crime groups pay special attention to the search and establishment of corruption ties among law enforcement officials, regulatory activities in the field of economics, judges, heads of local authorities, and other officials whose competence includes the adoption of important for organized crime groups solutions. This contributes to the increase in the number of corrupt officials who hold a responsible position. It should also be taken into account that corruption is characterized by a high level of latency (Dzhuzha, 2007; Pavlenko, 2013).

Representatives of a criminal enterprise for the purpose of realizing their participation in such specific illegal activities as operations with illicit goods and services, monopolization of the market, use of corruption, intimidation against competitors and law enforcement agencies in order to reduce the amount of prosecution (Hula, 2015; Sevruk, 2017).

A particular attention should be paid to the safety of life and health of a person, which is impossible without effective medicine, the protection of socially vulnerable groups of population, the safe state of the environment and access to quality drinking water, safe food, and manufactured goods;

$\checkmark$ the responsibility vector is to ensure that every citizen, regardless of race, colour, political, religious or other beliefs, gender, ethnic or social origin, property status, place of residence, language or other characteristics, will have access to high-quality education, healthcare systems, and other services in the public and private sectors. Territorial communities will independently resolve issues of local importance, their well-being, and will bear responsibility for the development of the entire country;

$\checkmark$ the vector of pride is to ensure mutual respect and tolerance in society, pride in its own state, its history, culture, science, and sport. Ukraine should take a worthy place among the leading countries of the world, create decent living and working conditions for the education of its own talents, as well as the attraction of the best world specialists from different fields (Pro Stratehiiu staloho rozvytku "Ukraina - 2020).

However, it should be noted that for products that are exported from Ukraine, there is a low level of use of the latest technologies. The volume of exports of domestic high-tech products in monetary terms during the last time grew. By the value of export, the dynamics were as follows: in 2010 - \$1441 million, 2011 - \$1908 million, 2012 - \$2623 million; in terms of percentage of hightech products in 2010 amounted to $4.3 \%$ in relation to the total volume of exported products, in 2011 $4.4 \%$, and in $2012-6.4 \%$. At the same time, it should be emphasized that Ukraine is far behind the leading countries in producing the abovementioned products: the share of high-tech goods in the total volume of exports of the Philippines was $48.9 \%$, Malta $-45.7 \%$, Singapore - 45.3\%, China - 26.3\%, Switzerland $25.8 \%$, France $-25.4 \%$, Great Britain - 21.7\%, United States $-17.8 \%$. On average, this indicator was $7.6 \%$ in 2012, in the EU countries - 15.4\% (World Bank Data).

The share of information and communication technologies in the total volume of exported products is even lower compared to the world index - in Ukraine this figure was $1.1 \%$ in 2012 , in the world $-10.4 \%$, in the EU countries - 5.3\%. It should be noted that the share of information and communication technologies in Ukraine during the last 10 years has not changed significantly, ranging from 0.5 to $1.5 \%$ (Naukova ta innovatsiina diialnist v Ukraini, 2013). The highest result for this indicator is observed in Hong Kong $42.2 \%$, in the Philippines - 29.5\%, in Singapore - 28.4\% (World Bank Data).

An important factor in the formation of an innovative economy in the country is the introduction of advanced technologies. In 2013, Ukraine received the 94th position under the sub-index "Technological readiness", having decreased by 13 points in comparison with 2012 (81st place). The first positions in the overall ranking of technological readiness of countries are Sweden, Luxembourg, Norway, Great Britain, Denmark. The highest level of access to state-of-the-art technologies is inherent in Finland, Sweden, Norway, Switzerland, and the United Kingdom. Ukraine occupies the last place in the components of the 
sub-index "Technological readiness": with the availability of the latest technologies - 106th place, the development of technology at the company level - 100th place, FDI and technology transfer - 131st place. Somewhat better indicators of technological readiness demonstrated by Ukraine on the level of access to the global Internet: by the number of people using the Internet 93rd place, according to the indicator of broadband Internet subscribers per 100 population - 71st place, by volume of Internet-traffic ( $\mathrm{Kb}$ per user) - 84th place, according to the indicator of mobile Internet users for 100 people - 94th place (The Global Competitiveness Report 2013-2014). Indicators indicate a low level of technology development in Ukraine.

The indicator of the innovative and intellectual development of the country is a high level of business competitiveness. In Ukraine, among the components of the sub-index "Business Competitiveness", six indicators belong to potential threats, three to critical backlogs. Relative competitive advantages are absent at all. Among the critical shortcomings, the following should be noted: the low level of state support for the development of clusters - 136th place, the nature of competitive advantage -112 th place (the base of a competitive prevailing country of cheap labour and cheap natural resources), readiness to delegate authority - 124th place. The result of Ukraine in the number (81st place) and quality (73rd place) of the local suppliers network, the presence of companies in the value chain (87th place), the control of domestic companies over distribution channels (60th place) is rather low, the complexity of production processes (97th place), using the marketing complex (77th place) (The Global Competitiveness Report 2013-2014). Thus, products produced by domestic companies are predominantly labour-intensive, based on outdated technologies, cheap labour and natural resources.

Thus, in the Ukrainian economy, there are such negative factors of influence:

1. The risks of the global economy. Decreasing the growth rates of the world economy. Activation of hostilities in eastern Ukraine.

2. Deployment of the Russian Federation "hybrid war" in new areas.

3. Aggravation of the domestic political crisis, in particular, the government and/or parliamentary crises.

4. Excessive inflation acceleration on the basis of "warming up" the consumer market, which will lead to too tight monetary policy, inhibition of capital investment, and inhibition of economic activity in general.

5. Excess of the planned devaluation indicator, set in the Budget.

Failure to achieve the expected additional revenues to the budget and the Pension Fund from raising the minimum wage that will force the budget gap to go through increased domestic borrowing and threaten macroeconomic destabilization, or forced monetary policy aggravated, or, alternatively, reducing budget expenditures, of which the most immediate development spending will be reduced (Stud, 2018).

Separately, an attention should be paid to ways of counteracting the shadow economy of Ukraine.

Thus, the sphere of activity of the shadow economy can be any activity that is defined by the state as legal, as well as illegal activities. Today, the shadow economy is most widespread in the following legal activities: production and distribution, in particular, productive capital; investment; bank stock exchange; insurance; resource-mining and distribution; provision of medical services; any intermediary activity, etc. (Lazareva, 2016).

According to O. V. Savych, I. V. Savych, the priorities of the state policy in the sphere of shadowing of the economy of Ukraine are: to improve existing methods of calculating the level of the shadow economy, taking into account world practice; creation of conditions for the de-socialization of the socio-political process; improving the efficiency of public finance management at all stages of planning your use of budget funds; improvement of foreign economic activity and improvement of interagency interaction; improvement of legislation in the field of combating economic crimes; stimulating the development of cashless settlements; improvement of fiscal administration; counteracting the shadow economy in the real sector by reducing transaction costs and improving the state licensing system; fighting corruption and raising the level of legal culture of the population; strengthening of the protection of rights to intellectual property objects; strengthening of economic security of the state in the process of deepening international and global economic integration (Savych, Savych, 2015).

Summing up, it should be noted that the task of counteracting the shadowing of the Ukrainian economy is particularly acute in the context of modern geopolitical challenges, European integration processes. The abovementioned directions of counteraction to the shadow economy of Ukraine form the main essential basis for the further elaboration of a comprehensive plan for the reduction of the economy of Ukraine. Countering the shadow economy of Ukraine requires the conduct of multidisciplinary research, the development of a comprehensive counteraction strategy in cooperation with foreign partners, primarily with a view to using their positive experience in combating this threatening phenomenon for national security (Savych, Savych, 2015).

Despite all of the above, it is necessary to create conditions that will ensure the successful reformation of the national economy of Ukraine. To do this, it is necessary: to form a real idea of national development; the existence of a single program of transformation, political will and a team of reformers; rapid (as much 
as possible) reform; economic liberalization (from the old bureaucratic system to transparent market relations) and a capable government; unity and consolidation of the whole society; ensuring the equivalence of the Ukrainian economy with the external economic environment; ensuring high social welfare and social protection of the population; the need for the ecological balance of the national economy; as soon as possible introducing an innovative model for the development of the national economy (Mazaraki, Melnyk, 2011).

In order to further develop the export potential of mechanical engineering, it is necessary to create innovative enterprises using technologies of 5-6 methods, to stimulate the development of production of new technology (for example, planes, ships) at certain operating enterprises under the proper state incentive policy. In our opinion, the following factors will influence the development of foreign trade in Ukraine in the future: significant share in the export of commodities and products with a relatively low value added will remain. In order to revive their exports, the improvement of the quality of goods will be of great importance through the technological modernization of metallurgical enterprises and the restoration of demand for metals on world markets; Ukraine's dependence on imports of energy resources will continue, although further reduction of gas consumption in industry can be expected in the conditions of increasing technological level of the main energy-consuming productions; the real final consumption of households, which was the driving force behind the growth of Ukraine's GDP over the past three years of pre-crisis, is steadily declining due to conservative wage labour policies and high inflation. The low solvency of households has an impact on imports in the direction of its cheapening, which will contribute to reducing the deficit of the trade balance. Ukrainian economy continues to suffer from loss; almost $40 \%$ of enterprises are loss-making and accumulating significant amounts of corporate debt. It is possible not only to restructure debts but also to use the mechanism of the bankruptcy of enterprises and change of owners to speed up the crisis (Mazaraki, Melnyk, 2011).

In the period up to 2020, the evolution of the European Union will take place with the transition from the prevalence of the territorial expansion policy to the policy of internal ordering and deepening of integration. The recent enlargement of the EU has led to a significant increase in the heterogeneity of its internal structure, due to a significant increase in differences not only in the levels of social and economic development but also in the institutional features of the participating countries. Understanding of these differences leads to an increase in the rejection of the further expansion of the functions of the communist bodies of the EU and, consequently, to the blocking of internal institutional reforms necessary for the extended existence. This objectively narrowing the field for the implementation of the policy of further EU enlargement, as within the framework of the old institutional mechanisms of the European Union, it could prove fatal to the fate of the EU itself. Under these conditions, the main efforts will be directed towards finding ways to strengthen the cooperation of the current members of the Union. At the same time, even the partial disintegration of the European Union with the formation within it of subregional integration groups with varying degrees of intensity of mutual relations (the model of concentric circles) is possible. It is important for Ukraine to reduce its gap with the EU countries as soon as possible in institutional, innovative development and living standards (Pro Stratehiiu staloho rozvytku "Ukraina - 2020").

Implementation of the Strategy involves the achievement of $25 \mathrm{key}$ indicators assessing progress in implementing reforms and programs:

1) in the World Bank's Doing Business Rating Ukraine will rank among the first 30 positions;

2) Ukraine's credit rating - Rating on liabilities in foreign currency on the scale of the rating agency Standard and Poor's - will not be lower than the investment category "BBB";

3) according to the World Economic Forum (WEF), the global competitiveness index, Ukraine will enter the top 40 countries of the world;

4) the gross domestic product (per purchasing power parity) per capita, calculated by the World Bank, will increase to $\$ 16,000$;

5) net inflows of foreign direct investment in the period of 2015-2020, according to the World Bank, will amount to more than $\$ 40$ billion;

6) the maximum ratio of the state budget deficit to the gross domestic product, according to the calculations of the International Monetary Fund, will not exceed 3 percent;

7) the maximum ratio of the total amount of public debt and guaranteed by the state debt to the gross domestic product, according to the calculations of the International Monetary Fund, will not exceed 60 percent (according to the Maastricht convergence criteria);

8) the energy intensity of the gross domestic product will be 0.2 tons of oil equivalent per $\$ 1000$ of the gross domestic product, according to the International Energy Agency;

9) expenses for national security and defence will amount to not less than 3 percent of the gross domestic product; 10) the number of professional soldiers per 1,000 population will increase from 2.8 to 5.6 persons according to the Stockholm International Peace Research Institute;

11) according to the Transparency International Corruption Perceptions Index, Ukraine will enter the top 50 countries of the world;

12) according to the results of the survey, the level of confidence of the expert environment (lawyers) in court will be 70 percent; 
13) according to the results of a national survey, the level of public confidence in the law enforcement bodies will be 70 percent;

14) updating the personnel of civil servants in law enforcement agencies, courts and other state bodies by 70 percent;

15) the limit of the share of one supplier in the total amount of purchases of any energy resources will be no more than 30 percent;

16) the average life expectancy of a person will increase by 3 years;

17) the share of local budgets will be at least 65 percent in the consolidated state budget;

18) the share of penetration of broadband Internet, according to the World Bank, will be 25 subscribers per 100 people;

19) 75 percent of graduates of secondary education establishments will have at least two foreign languages, which will be confirmed by international certificates;

20) Ukraine will take part in the international study on the quality of education PISA and will be included in the top 50 countries of the study;

21) Ukraine, together with the World Bank, will develop an indicator of the welfare of citizens, will be determined by its target values and will monitor the changes of such indicator;

22) according to the results of a nationwide poll, 90 percent of Ukrainian citizens will be proud of their state;

23) Ukraine will win at least 35 medals during the XXXII Summer Olympic Games;

24) Global Competitiveness Index in the talent struggle, which is expected by one of the world's leading business schools INSEAD), Ukraine will be among the top 30 nations in the world;

25) 20 films of Ukrainian production will be released in 2020 (Pro Stratehiiu staloho rozvytku "Ukraina 2020").

Summarizing all of the above, we think it is necessary to pay attention to the rationale of innovations in Ukraine separately. One of the most important factors of the competitiveness of the economy is the innovation of the country. The only relative competitive advantage of Ukraine for this criterion is the availability of scientists and engineers, which ranked 46th among 148 countries, according to the estimates of the WEF. Relatively high is the ranking of Ukraine in quality of research institutions -69 th place, with the cooperation of universities and enterprises in the field of research and development -77 th place, by the number of patents per million population - 52nd place. Worst result Ukraine demonstrates for the capacity for innovation 100th place, the cost of research and development companies - 112th place, state procurement of advanced technological products - 118th place (The Global Competitiveness Report 2013-2014).
The cost of research and development is one of the main indicators of the level of innovation development in the country. The intensity of research and development (research and development as a percentage of GDP) is used as an indicator of the relative size of investment in creating new knowledge. The highest rate of research and development intensity is characteristic of Israel - 4.38\% of GDP in 2011. The following positions are: Korea $4.03 \%$, Finland $-3.78 \%$ of GDP; Japan $-3.39 \%$ of GDP; Sweden $-3.37 \%$ of GDP; Iceland $-3.11 \%$ of GDP; Denmark - 3.09\% of GDP; Germany - $2.88 \%$ of GDP; Switzerland $-2.87 \%$ of GDP; The United States $-2.77 \%$ of GDP (OECD Science, Technology and Industry Scoreboard 2013. Innovation for Growth).

In general, the intensity of research and development in the EU is $1.94 \%$ of GDP, in OECD countries $-2.37 \%$ of GDP. In the CIS countries (except for the Russian Federation, where this figure was $1.2 \%$ of GDP), the share of research and development costs is less than $1 \%$ of GDP. In Ukraine, the intensity of research and development amounted to $0.75 \%$ of GDP in 2012, in $2011-0.73 \%$. The highest intensity of research and development in Ukraine was observed in the period from 2000 to 2005 . At that time, the share of research and development expenses amounted to $1.1-1.2 \%$ of GDP (Naukova ta innovatsiina diialnist v Ukraini, 2013).

In general, it should be noted that ensuring the sustainable economic growth of Ukraine's economy requires solving a number of important problems. In Ukraine, it is necessary to implement the principles of continuous increase of competitiveness by eliminating critical backlogs, which relates above all to factors that are crucial for an efficiently oriented stage of economic development (according to the classification of the modern economic systems of the WEF). These are the critical lag behind the following rating criteria: "Efficiency of commodity markets" (where Ukraine ranks 124th among 148 countries of the world) and "Efficiency of the financial market" (117th place). The level of technological readiness of the country (94th place) is also quite low, which poses a potential threat to Ukraine's economic development and its competitiveness.

At the same time, ensuring competitiveness is impossible without a proper level of basic factors. Therefore, there are good reasons to state that the most important problems that require urgent resolution are the reorganization of the institutional system, the ineffectiveness of which results in excessive administration being carried out within the existing state regulation practice. The bureaucracy, the lack of transparency, and the corruption of the state apparatus also negatively affect the state of Ukraine's competitiveness (Ukraine occupies the 137th place by this indicator). Significantly, especially taking into account the latest developments in the history 
of Ukraine, there is the provision of macroeconomic stability. As of 2013, Ukraine ranked 107th for this indicator.

\section{Conclusion}

Correction of economic policy does not affect its strategic directions. Its basic positions remain unchanged: the transformation of the economy and the implementation of this process at an accelerated pace, despite all the opposition to the conservative forces. The young Ukrainian state faces extremely complex and important tasks in the field of the economy. On their solution, our progress towards a civilized life depends to a large extent. Therefore, the implementation of the economic program of the newest Ukrainian state should become a bloody affair of every citizen of the country.

In order to reduce the impact of the global crisis on Ukraine's economy and its foreign trade, political will and the coherence of government, business and society as a whole are needed. The export potential of the Ukrainian economy and the need for import revenues are reflected in its foreign trade balance, which requires constant research of factors and ways of the least painful way out of the crisis and ensuring the next effective rise (Mazaraki, Melnyk, 2011). Thus, Ukraine's economic development today requires, as ever, a well-balanced and sound macroeconomic policy aimed at further stabilization. Since the radical socioeconomic transformations that took place during the last decade have caused both positive and negative changes in Ukrainian (Pavlenko, Sevruk, Kobko, 2017). Ultimately, it becomes clear that the time has already come for the development of the Ukrainian economy's development strategy on an innovative basis and the adoption of relevant legislative acts, the experience of which is being developed and implemented in many countries of the world, including the countries of the European Union - Great Britain, Germany, Poland (National Academy of Sciences of Ukraine, 2015). In this regard, today it is necessary to analyse in detail the already existing legislative framework regulating innovation activity in Ukraine, and the introduction of effective proposals for the change of such a base taking into account the tasks of modernizing the economy on an innovative basis (Yunin, Sevruk, Pavlenko, 2018).

\section{References:}

Ekonomika Ukrainy $v$ umovakh nezalezhnosti: problemy ta perspektyvy [Ukraine's economy in the conditions of independence: Problems and perspectives]. Retrieved from: http://ru.osvita.ua/vnz/reports/econom history/24818/ (in Ukrainian)

Pro Stratehiiu staloho rozvytku "Ukraina - 2020" [On Strategy of Sustainable Development "Ukraine - 2020"]. Retrieved from: http://zakon.rada.gov.ua/laws/show/5/2015 (in Ukrainian)

Stud, Yu. S. (2018). Osnovni chynnyky rozvytku ekonomiky Ukrainy [Key development factors of economy of Ukraine]. XVII Vseukrainska naukova konferentsiya molodykh uchenykh ta studentiv "Naukovi rozrobky molodi na suchasnomu etapi". (in Ukrainian)

Shkurupii, O. V., Bazavluk, N.H. (2014). Chynnyky dynamiky ekonomiky Ukrainy ta natsionalnoi konkurentospromozhnosti [Factors of Dynamics of Ukraine's Economy and National Competitiveness]. Problemy ekonomiky, 2, 89-94. (in Ukrainian)

Melnykova, V. I., Melnykova, O. P., Sidliaruk T. V., Tur, I. Yu., Shvedova, H. M. (2011). Natsionalna ekonomika. Navch. posib. K.: Center for Educational Literature, 248 p. (in Ukrainian)

Sevruk, V. H. (2014). Svitovyi dosvid zapobihannia ta protydii koruptsii: intehratsiia Ukrainy do YES [World experience of prevention and counteraction of corruption: Ukraine's integration into EU]. Proceedings from the Round table on Use of Special Knowledge in Investigation of Corruption Offenses. Kyiv, November 20. K.: National Academy of Internal Affairs. (in Ukrainian)

Pohoretskyi, M. A. (2007). Orhanizovana zlochynnistvUkraini: tendentsii rozvytku ta zakhody protydii [Organized crime in Ukraine: Development trends and measures of counteraction]. Borotba z orhanizovanoiu zlochynnistiu $i$ koruptsiieiu (teoriia i praktyka), 16, 99-110. Retrieved from: http://nbuv.gov.ua/UJRN/boz_2007_16_9

Pavlenko, S. O. (2017). Taktyka vyiavlennia orhanizovanoi zlochynnosti z korumpovanymy zviazkamy [Tactics of detection of organized crime with corrupt bonds]. Proceedings from II International Scientific and Practical Conference on Implementation of State Anti-Corruption Policy in International Dimension. Kyiv, December 8. V. V. Cherniei, S. D. Husariev, S. S. Cherniavskyi et al. (Eds.). Kyiv: National Academy of Internal Affairs. (in Ukrainian)

Dzhuzha, O. M. (2007). Orhanizovana zlochynnist v Ukraini ta krainakh Yevropy: posibnyk [Organized crime in Ukraine and European countries: teaching manual]. K.: Kyiv National University of Internal Affairs, 248 p. (in Ukrainian)

Pavlenko, S. O. (2013). Deiaki osoblyvosti protydii khabarnytstvu, vchynenomu sluzhbovymy osobamy, yaki zaimaiut vidpovidalne stanovyshche [Some features of counteraction to bribery committed by officials in responsible positions]. Borotba z orhanizovanoiu zlochynnistiu i koruptsiieiu (teoriia i praktyka), 2(30), 279-288.

Hula, L. F. (2015). Orhanizovana zlochynna hrupa - osnova orhanizovanoi zlochynnosti [Organized criminal group - the basis of organized crime]. Naukovyi visnyk Lvivskoho derzhavnoho universytetu vnutrishnikh sprav, 1, 365-376. 
Sevruk, V. H. (2017). Koruptsiynyi aspekt diialnosti orhanizovanykh hrup etnichnykh i zlochynnykh orhanizatsii, sformovanykh na etnichnii osnovi [Corruption aspect of activities of organized groups of ethnic and criminal organizations formed on ethnic basis]. Proceedings from II International Scientific and Practical Conference on Implementation of State Anti-Corruption Policy in International Dimension. V. V. Cherniei, S. D. Husariev, S. S. Cherniavskyi et al. (Eds.). Kyiv: National Academy of Internal Affairs. (in Ukrainian)

World Bank Data. Retrieved from: http:// data.worldbank.org/indicator

Naukova ta innovatsiina diialnist v Ukraini: stat. zb. (2013). [Scientific and innovation activity in Ukraine: Data set]. K.: Information and Publishing Center of the State Statistics Service of Ukraine, 287 p. Retrieved from: http://ukrstat.gov.ua (in Ukrainian)

The Global Competitiveness Report 2013-2014. Retrieved from:_http://www3.weforum.org/docs/WEF_Global CompetitivenessReport_2013-14.pdf.

Lazareva, A. (2016). Vplyv tinovoi ekonomiky na ekonomichnu bezpeku derzhavy [Influence of the shadow economy on the economic security of the state]. Ekonomiko-pravova paradyhma rozvytku suchasnoho suspilstva. Retrieved from: https://studlib.org.ua/index.php/eprs/article/view/78/74 (in Ukrainian)

Savych, O. V., Savych, I. V. (2015). Osnovni chynnyky ta shliakhy protydii tinizatsii ekonomiky Ukrainy [The main factors and ways of counteracting the shadow economy of Ukraine]. Efektyvna ekonomika. Retrieved from: http://www.economy.nayka.com.ua/?op=1\&z=3827 (in Ukrainian)

Mazaraki, T., Melnyk, T. (2011). Suchasni tendentsii ta chynnyky rozvytku zovnishnoi torhivli Ukrainy [Modern Trends and Factors in Development of Foreign Trade of Ukraine]. Visnyk Kyyivskoho natsionalnoho torhovelnoekonomichnoho universytetu, 2, 5-14. (in Ukrainian)

OECD Science, Technology and Industry Scoreboard 2013. Innovation for Growth. Retrieved from: http: / / www.oecd-ilibrary.org/docserver/download/9213051 e.pdf?expires=1400226235\&id=id\&accname= guest\&checksum =FF68A22CD562561EFFA8B65FF059BD77

Pavlenko, S. O., Sevruk, V. G., Kobko, Ye. V. (2017). Training police officers in the conditions of reforming the system of education of the Ministry of Internal Affairs of Ukraine in accordance with European standards. Nauka i osvita, 6, 142-150.

National Academy of Sciences of Ukraine. (2015). Innovatsiina Ukraina 2020: natsionalna dopovid [Innovative Ukraine 2020: National report]. V. M. Heits, et al. (Eds). K., 336 p. (in Ukrainian)

Yunin, O., Sevruk, V., Pavlenko, S. (2018). Priorities of economic development of Ukraine in the context of European integration. Baltic Journal of Economic Studies, 4(3), 358-365. 